\title{
Pengaruh Suhu Wet Rendering yang Berbeda terhadap Karakteristik Ekstrak Kasar Minyak Ikan Lele (Clarias sp.)
}

\author{
Effect of Wet Rendering Temperature on Crude Oil Characteristics from Catfish (Clarias sp.) Viscera
}

Magdalena Januasni Jati Martins, Lukita Purnamayati*, R. Romadhon

\begin{abstract}
Program Studi Teknologi Hasil Perikanan, Fakultas Perikanan dan Ilmu Kelautan, Universitas Diponegoro, Jl. Prof. Soedarto, SH., Tembalang, Semarang 50275, Indonesia

*Korespondensi penulis: Lukita Purnamayati, Email: lukita_anandito@yahoo.com
\end{abstract}

Tanggal submisi: 22 September 2019; Tanggal revisi: 27 Juli 2020; Tanggal penerimaan: 3 September 2020

\begin{abstract}
ABSTRAK
Pengolahan minyak isi perut ikan lele dapat meningkatkan nilai ekonomi limbah ikan lele. Wet rendering merupakan metode yang sering digunakan untuk mengekstrak minyak ikan. Metode ini menggunakan panas dan air untuk membantu proses ekstraksi. Perlakuan suhu bertujuan untuk menggumpalkan protein dan merusak membran sel sehingga minyak dapat terekstrak keluar. Adanya air memudahkan pemisahan karena minyak yang terekstrak akan mengapung pada permukaan. Penggunaan suhu ekstraksi berpengaruh terhadap kualitas minyak ikan yang dihasilkan. Suhu ekstraksi yang tinggi menyebabkan penurunan kualitas minyak akibat terjadinya reaksi oksidasi. Tujuan penelitian ini adalah untuk mengetahui pengaruh suhu ekstraksi wet rendering terhadap karakteristik ekstrak kasar minyak isi perut ikan lele dan mengetahui suhu ekstraksi optimum berdasarkan karakteristik ekstrak minyak isi perut ikan lele yang dihasilkan. Penelitian ini menggunakan rancangan acak lengkap dengan satu faktor yaitu perbedaan suhu ekstraksi wet rendering $\left(80^{\circ} \mathrm{C}, 90^{\circ} \mathrm{C}\right.$, dan $\left.100^{\circ} \mathrm{C}\right)$ dengan tiga kali pengulangan. Hasil penelitian menunjukkan bahwa semakin tinggi suhu ekstraksi menghasilkan minyak isi perut ikan lele dengan rendemen yang semakin meningkat. Namun, kualitas minyak ikan semakin menurun yang ditunjukkan dengan meningkatnya asam lemak bebas dan angka peroksida, yang berakibat pada penurunan nilai organoleptik, perubahan profil asam lemak dan slip melting point. Suhu $100^{\circ} \mathrm{C}$ merupakan suhu ekstraksi terbaik dengan nilai organoleptik 7,87; rendemen 8,57\%; slip melting point $37,53{ }^{\circ} \mathrm{C}$; bilangan iod $16,01 \%$; total SFA 42,9\%; MUFA 31,8\%; PUFA 11,51\%; angka asam lemak bebas 2,00\%; kadar air 0,56\%; dan bilangan peroksida 7,26 meq/kg.
\end{abstract}

Kata kunci: Ikan lele; minyak ikan; suhu ekstraksi; wet rendering

\begin{abstract}
The processing of catfish oil from viscera can increase the economic value of catfish waste. Wet rendering is a method often used to extract fish oil. This method uses heat and water to accelerate the extraction process. The temperature treatment aims to coagulate proteins and damage cell membranes so oil can be extracted. The presence of water eases the extraction because the extracted oil will float on the surface of the water. The extraction temperature affects the quality of the fish oil produced. High extraction temperatures decrease oil quality due to oxidation reactions. The purpose of this study was to determine the effect of wet rendering extraction temperature on the characteristics of crude catfish oil from viscera and determine the optimum
\end{abstract}


extraction temperatures based on its characteristics. This study used a completely randomized design with one factor, namely differences in wet rendering extraction temperatures $\left(80^{\circ} \mathrm{C}, 90^{\circ} \mathrm{C}\right.$, and $\left.100^{\circ} \mathrm{C}\right)$ in triplicates. The results showed that a higher extraction temperature increased the yield of crude oil. However, the quality of fish oil decreased as indicated by the increase in free fatty acids and peroxide value that decreased the organoleptic values and changed the fatty acid profile and slip melting point. The temperature of $100^{\circ} \mathrm{C}$ was the best extraction temperature with an organoleptic value of 7.87 ; yield of $8.57 \%$; slip melting point of $37.53{ }^{\circ} \mathrm{C}$; iodine number of $16.01 \%$; total SFA of $42.9 \%$; MUFA of $31.8 \%$; PUFA of $11.51 \%$; free fatty acid of $2.00 \%$; water content of $0.56 \%$; and peroxide value of $7.26 \mathrm{meq} / \mathrm{kg}$.

Keywords: Catfish; extraction temperature; fish oil; wet rendering

\section{PENDAHULUAN}

Ikan lele (Clarias sp.) merupakan salah satu komoditas budidaya air tawar yang produksinya terus meningkat dan menurut KKP (2017), perkembangan produksi lele secara nasional sebesar 719,619 ton pada tahun 2015, meningkat tahun 2016 sebesar 764,797 ton dan pada tahun 2017 meningkat pesat menjadi $1,095,969$ ton. Tingginya produksi ikan lele seiring dengan meningkatnya jumlah limbah yang dihasilkan. Isi perut merupakan salah satu limbah yang dihasilkan dari pengolahan ikan lele. Limbah isi perut ikan lele terdiri dari saluran pencernaan, hati, empedu, dan lemak abdomen. Isi perut mengandung beberapa asam lemak potensial yaitu asam linoleat $13,52 \%$, asam laurat $37,24 \%$, asam oleat $6,04 \%$, asam palmitat $12,86 \%$, dan asam stearat $1,32 \%$, sedangkan lemak abdomen mengandung asam linoleat (omega-6) 19,97\%, asam oleat (omega-9) 40,14\%, dan asam palmitat 26,22\% (Ayu dkk., 2019; Effiong \& Fakunle, 2013). Dilihat dari kandungan asam lemak tak jenuh tersebut maka isi perut ikan lele sangat berpotensi untuk dikembangkan lebih lanjut menjadi minyak ikan yang kaya akan omega 6 dan omega 9 yang bermanfaat untuk kesehatan. Elbossaty (2018) menyatakan bahwa asam lemak omega 6 bermanfaat untuk menurunkan resiko penyakit diabetes tipe 2 dan menurunkan kolesterol, sedangkan asam lemak omega 9 bermanfaat untuk meningkatkan daya tahan tubuh dan mencegah penyakit jantung.

Beberapa metode ekstraksi dilakukan untuk memperoleh minyak ikan antara lain ekstraksi menggunakan pelarut, silase ikan, fluida superkritis dan rendering. Ekstraksi menggunakan pelarut efektif untuk mengekstrak seluruh komponen pada bahan, tetapi metode ini memerlukan waktu yang lama, sampel yang kering dengan luas permukaan yang besar, dan meninggalkan residu pelarut. Silase ikan adalah metode ekstraksi dengan menambahkan asam, enzim, atau bakteri asam laktat untuk menghidrolisis protein. Metode ini efektif untuk ekstraksi minyak ikan karena tidak menggunakan pelarut dan dapat mencegah oksidasi lemak. Akan tetapi, penambahan asam dapat menyebabkan ekstrak terdegradasi terutama pada profil asam lemak. Selain itu, penggunaan enzim atau bakteri asam laktat diperlukan pengaturan kondisi dan waktu inkubasi agar ekstraksi dapat bekerja optimal. Fluida superkritis merupakan teknologi yang digunakan untuk mendapatkan minyak ikan berkualitas tinggi. Metode ini menggunakan suhu rendah dan media yang bebas oksigen sehingga oksidasi omega-3 selama ekstraksi dapat dihindari. Kelemahan metode ini adalah membutuhkan biaya yang mahal (Bonilla-Mendez \& Hoyos-Concha, 2018; Deepika dkk., 2014; Nazir dkk., 2017).

Rendering merupakan metode ekstraksi minyak ikan dengan memberikan perlakuan panas pada bahan. Penggunaan suhu dalam ekstraksi minyak ikan bertujuan untuk merusak jaringan dengan menggumpalkan protein pada dinding sel sehingga minyak dapat terekstrak keluar. Metode ini sangat sederhana dan tidak membutuhkan bahan kimia (Kamini dkk., 2016; Nazir dkk., 2017). Metode rendering terdiri dari dry rendering dan wet rendering. Metode wet rendering lebih banyak digunakan untuk ekstraksi karena menghasilkan rendemen minyak yang lebih banyak dibandingkan dry rendering (Taati dkk., 2018). Selain itu, metode ekstraksi wet rendering menghasilkan minyak ikan lele dengan kualitas yang lebih baik ditinjau dari angka asam lemak bebas, bilangan peroksida dan pengujian organoleptik dibandingkan dengan metode dry rendering (Eka dkk., 2016).

Suhu yang digunakan dalam proses ekstraksi berpengaruh terhadap karakteristik minyak ikan yang dihasilkan. Suhu yang semakin tinggi dapat memicu pembentukan radikal bebas dan proses oksidasi sehingga kualitas minyak ikan menurun, namun suhu ekstraksi yang rendah tidak mampu menghasilkan rendemen minyak yang maksimal. Bako dkk (2017) menyatakan bahwa semakin tinggi suhu ekstraksi maka rendemen minyak ikan makerel yang dihasilkan semakin meningkat. Penggunaan suhu $60{ }^{\circ} \mathrm{C}$ menghasilkan rendemen minyak ikan sebesar $18,6 \%$. Angka ini lebih rendah dibandingkan dengan 
penggunaan suhu ekstraksi $90{ }^{\circ} \mathrm{C}$ yang menghasilkan rendemen minyak ikan sebesar $22 \%$. Suseno dkk. (2015) menyatakan bahwa ekstraksi menggunakan suhu $90{ }^{\circ} \mathrm{C}$ menghasilkan minyak ikan dengan angka peroksida yang lebih tinggi dibandingkan dengan ekstraksi suhu $70{ }^{\circ} \mathrm{C}$. Penelitian lain menyebutkan bahwa suhu ekstraksi $100^{\circ} \mathrm{C}$ menghasilkan kualitas minyak ikan terbaik dengan asam lemak bebas 3,1\%, angka asam 5,97 mgKOH/mg, dan kadar air 0,14\% (ElRahman dkk., 2018), sedangkan suhu optimum limbah usus ikan nila adalah $80^{\circ} \mathrm{C}$ dengan karakteristik asam lemak bebas 3,91\%, bilangan peroksida $17,51 \mathrm{meq} / \mathrm{kg}$, kadar air 0,91\% dan nilai organoleptik 7,4 (Nugroho dkk., 2014). Oleh karena itu, diperlukan suhu yang optimum untuk ekstraksi dengan metode wet rendering untuk mendapatkan minyak isi perut ikan lele dengan rendemen dan kualitas yang optimum pula.

Penelitian mengenai karakteristik minyak dari isi perut ikan telah banyak dilakukan oleh beberapa peneliti (El-Rahman dkk., 2018; Fouda, 2018; Sugeng Heri Suseno dkk., 2015), namun untuk optimasi suhu dengan metode ekstraksi wet rendering pada isi perut ikan lele belum pernah dilakukan. Tujuan penelitian ini adalah mengetahui pengaruh suhu ekstraksi wet rendering terhadap karakteristik ekstrak kasar minyak isi perut ikan lele dan mengetahui suhu optimum ekstraksi wet rendering terbaik berdasarkan karakteristik ekstrak kasar minyak isi perut ikan lele.

\section{METODE PENELITIAN}

Penelitian dilakukan dengan metode eksperimental laboratoris. Percobaan dirancang dengan Rancangan Acak Lengkap dengan perlakuan suhu ekstraksi yang berbeda, yaitu $80^{\circ} \mathrm{C}, 90^{\circ} \mathrm{C}$, dan $100^{\circ} \mathrm{C}$. Masing-masing perlakuan diulang tiga kali. Variabel mutu produk yang diamati adalah organoleptik, rendemen, bilangan iod, slip melting point, profil asam lemak, angka asam lemak bebas, kadar air, dan bilangan peroksida.

\section{Alat dan Bahan}

Bahan utama yang digunakan dalam penelitian ini adalah isi perut ikan lele yang diperoleh dari Pasar Bandarjo (Ungaran, Indonesia) dan aquades yang diperoleh dari Toko Kimia Indrasari (Semarang, Indonesia).

Alat-alat yang digunakan dalam penelitian ini adalah blender dengan kapasitas 1,5 L (Miyako Blender 152GF, Indonesia), waterbath (WiseBath WB Digital Precise Water Bath, Italia), sentrifus (Hettich Mikro 200-200 R, Jerman), dan alat-alat untuk pengujian karakteristik di laboratorium.

\section{Ekstraksi Minyak Ikan}

Ekstraksi minyak ikan lele dilakukan dengan menggunakan metode El-Rahman dkk. (2018) yang dimodifikasi pada bagian lama waktu rendering. Proses ekstrak kasar minyak isi perut ikan lele dilakukan dengan menggunakan metode ekstraksi wet rendering dengan perlakuan suhu yang berbeda. Sebanyak $400 \mathrm{~g}$ isi perut ikan lele dibersihkan dan dihaluskan menggunakan blender kemudian ditambahkan aquades dengan perbandingan sampel : aquades (1:1) (b/v), setelah itu dilakukan proses rendering menggunakan waterbath dengan suhu ekstraksi $80{ }^{\circ} \mathrm{C}(\mathrm{A}), 90^{\circ} \mathrm{C}(\mathrm{B})$, dan $100{ }^{\circ} \mathrm{C}(\mathrm{C})$ selama 40 menit. Ekstrak disaring menggunakan kertas saring Whatmann 41, kemudian dilakukan sentrifus $3000 \mathrm{rpm}$ selama 10 menit untuk memisahkan bagian minyak dari air dan padatannya. Minyak kasar yang diperoleh dikemas dalam botol kaca dan dilapisi alumunium foil untuk menghindari kontak langsung dengan cahaya. Minyak kasar disimpan pada suhu $\pm 5^{\circ} \mathrm{C}$ untuk selanjutnya dilakukan pengujian terhadap mutu produk.

\section{Analisis Karakteristik Ekstrak Kasar Minyak Isi Perut Ikan Lele}

Karakteristik ekstrak kasar minyak ikan secara fisika meliputi rendemen (AOAC, 1995), dan slip melting point (AOCS, 1997). Analisis kimia minyak ikan yaitu uji bilangan iod (BSN, 1998), profil asam lemak (AOAC, 2007), asam lemak bebas (AOAC, 2007), kadar air (AOAC, 1995), dan bilangan peroksida (AOAC, 1995). Uji organoleptik dilakukan berdasarkan SNI 2730.1: 2013 menggunakan metode scoring dengan skala penilaian 1-9. Nilai 1 untuk kualitas minyak ikan yang buruk yang ditunjukkan dengan kenampakan minyak kotor, warna hitam pekat dan bau tengik, sedangkan nilai 9 untuk kualitas minyak yang baik, ditunjukkan dengan kenampakan minyak cerah, bersih, warna kuning kecoklatan, dan bau sangat kuat spesifik minyak ikan. Pengujian dilakukan dengan melibatkan 30 panelis semi terlatih (BSN, 2013).

\section{Analisis Statistik}

Data hasil uji dianalisis dengan menggunakan uji normalitas dan homogenitas dan dilakukan dengan uji one-way ANOVA apabila data berdistribusi normal dan homogen. Jika terdapat perbedaan yang nyata $(p>0,05)$ maka dilanjutkan dengan uji Beda Nyata Jujur (BNJ) untuk mengetahui perbedaan atau membandingkan antar nilai tengah perlakuan dan menentukan perlakuan yang terbaik. Analisis data organoleptik menggunakan uji Kruskal Wallis dan dilanjutkan dengan uji Mann Whitney Jika terdapat perbedaan yang nyata (David \& Djamaris, 2018). 


\section{HASIL DAN PEMBAHASAN}

\section{Kadar Air dan Lemak Isi Perut Ikan Lele}

Hasil uji kadar air isi perut ikan lele yang digunakan sebagai bahan baku pembuatan ekstrak kasar minyak ikan memiliki persentase sebesar 75,97\%, sedangkan kadar lemak sebesar 8,29\%. Nilai kadar air pada penelitian ini lebih rendah dibandingkan isi perut ikan mujair sebesar 79,3\% (Hildawianti dkk. 2017). Persentase kadar lemak isi perut ikan lele pada penelitian ini juga lebih rendah dibandingkan kadar lemak ikan nila dan ikan bandeng yaitu masing-masing sebesar 1,69\% dan 2,23\% (Devadason dkk., 2016). Hal ini dikarenakan perbedaan jenis spesies memiliki kandungan kadar air dan kadar lemak yang berbeda (Yesmin \& Khanum, 2019). Selain itu, juga dipengaruhi oleh umur, jenis kelamin, tempat hidup, dan asupan makanan (Edea dkk., 2018; Obaroh dkk., 2015).

Tabel 1. Kandungan pada isi perut ikan lele

\begin{tabular}{lc}
\hline \multicolumn{1}{c}{ Komposisi } & Persentase (\%) \\
\hline Kadar air & $75,97 \pm 0,40$ \\
Kadar abu & $8,29 \pm 1,95$ \\
\hline
\end{tabular}

\section{Karakteristik Minyak Ikan Lele}

Minyak isi perut ikan lele yang diekstrak dengan suhu wet rendering yang berbeda kemudian dianalisa secara fisika yang meliputi uji organoleptik, rendemen dan shot melting point, sedangkan analisa secara kimia meliputi uji bilangan iod, kadar air, asam lemak bebas, dan bilangan peroksida (Tabel 2).

Parameter uji organoleptik minyak ikan kasar meliputi nilai kekeruhan, warna dan bau. Hasil pengujian nilai kekeruhan diperoleh bahwa semakin tinggi suhu ekstraksi yang digunakan maka nilai kekeruhan minyak ikan semakin meningkat, yang ditunjukkan pada sampel minyak A lebih jernih daripada sampel C. Kekeruhan minyak diduga berasal dari sisa produk degradasi akibat proses ekstraksi minyak dengan suhu tinggi. Selain itu, pengambilan lapisan minyak setelah proses sentrifus dengan menggunakan pipet menyebabkan beberapa filtrat ikut terbawa bersama minyak. Menurut Suseno dkk. (2012), jumlah absorben, waktu pengolahan dan suhu dapat mempengaruhi kenampakan dari minyak ikan.

Sampel minyak ikan A memiliki warna kuning muda, sedangkan sampel B berwarna kuning keemasan dan sampel $\mathrm{C}$ berwarna kuning sedikit kecoklatan. Penggunaan suhu ekstraksi yang semakin tinggi maka proses oksidasi semakin meningkat sehingga

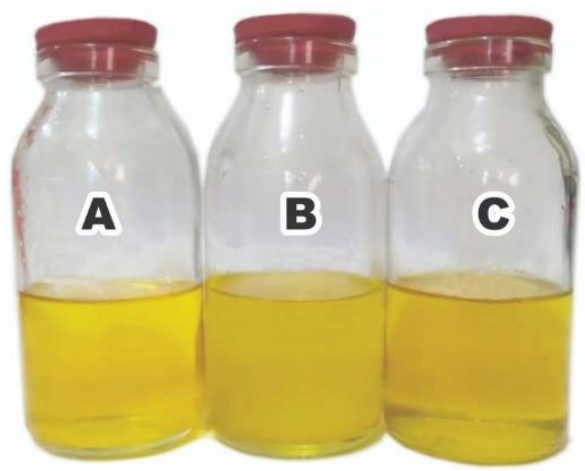

Gambar 1. Minyak ikan lele dengan suhu ekstraksi $80^{\circ} \mathrm{C}(\mathrm{A})$, $90^{\circ} \mathrm{C}(\mathrm{B})$ dan $100^{\circ} \mathrm{C}(\mathrm{C})$

menimbulkan warna kecoklatan. Hasil ini sesuai dengan Widiyanto dkk. (2015) yang menyatakan bahwa semakin tinggi suhu ekstraksi menghasilkan perubahan warna minyak ikan dari kuning menjadi kecoklatan karena adanya proses oksidasi yang menyebabkan pigmen karotenoid memudar. Suseno dkk. (2012) juga menyebutkan bahwa peningkatan suhu menyebabkan perubahan warna minyak ikan akibat perubahan pigmen karotenoid seperti astaxantin dan cantaxantin.

Sampel minyak A memiliki bau yang spesifik minyak ikan, sampel B memiliki bau spesifik minyak ikan yang sedikit berkurang, sedangkan pada sampel minyak C sedikit berbau asam. Akan tetapi, sampel minyak C masih memenuhi persyaratan uji organoleptik minyak ikan. Wijaya dkk., (2019) menyatakan bahwa persyaratan minyak ikan berdasarkan SNI 2730.1:2013 untuk nilai organoleptik adalah 7 dengan kriteria bau sedikit asam tetapi bukan tengik. Semakin tinggi suhu yang digunakan saat ekstraksi maka bau spesifik minyak ikan semakin berkurang. Bau spesifik minyak ikan adalah bau alamiah yang terdapat pada bahan yang ikut terbawa saat proses ekstraksi. Minyak ikan kasar masih mengandung komponen selain minyak yaitu asam lemak bebas, fosfatida, produk oksidasi, air dan produk lain yang mempengaruhi bau (Ayu dkk., 2019; Hasanah dkk., 2017). Hasil ini berhubungan dengan data angka asam lemak bebas dan angka peroksida yang semakin meningkat seiring dengan meningkatnya suhu ekstraksi, yang diduga mengakibatkan menurunnya nilai parameter bau minyak isi perut ikan lele.

Hasil rerata rendemen tertinggi diperoleh pada sampel minyak ikan C sebesar $8,57 \%$ sedangkan terendah pada sampel minyak ikan A sebesar 3,40\%, yang tidak berbeda nyata dengan sampel $B$ yaitu sebesar 5,15\%. Menurut Nugroho dkk. (2014), penggunaan suhu yang semakin tinggi maka semakin banyak minyak yang dihasilkan, karena suhu yang tinggi dapat merusak 
dinding sel sehingga mudah ditembus oleh minyak. Rendemen minyak ikan yang diperoleh berkisar antara 3,40-8,57\% dimana hasil tersebut lebih tinggi daripada minyak ikan lele murni yaitu sebesar 2,20\% (Aditia dkk., 2014), namun lebih rendah dibandingkan minyak ikan lele yang diekstrak menggunakan metode dry rendering yaitu sebesar 13,3\% (Eka dkk., 2016). Metode ekstraksi minyak ikan dan bagian tubuh ikan yang diekstrak memberikan pengaruh terhadap rendemen minyak ikan yang dihasilkan.

Slip melting point (SMP) merupakan suhu dimana terjadi perubahan wujud minyak dari padat menjadi cair. Titik leleh terendah ditunjukkan oleh sampel $A$ yaitu 29,27 ${ }^{\circ} \mathrm{C}$, sedangkan pada sampel $\mathrm{B}$ dan $\mathrm{C}$ masingmasing sebesar $35,43^{\circ} \mathrm{C}$ dan $37,53^{\circ} \mathrm{C}$, hal ini menunjukan bahwa sampel $\mathrm{A}$ memiliki kandungan asam lemak tak jenuh yang lebih tinggi daripada kedua sampel lainnya. Menurut Ngadiarti dkk. (2013), titik leleh berhubungan dengan struktur kimia asam lemak. Titik cair yang rendah menunjukan semakin meningkatnya jumlah ikatan rangkap asam lemak. Hasil SMP sampel A merupakan hasil terbaik karena minyak mudah mencair pada suhu ruang. Menurut Raharjo dkk. 2017), titik leleh yang baik adalah yang mendekati suhu badan dan memiliki tingkat kekerasan yang mínimum pada suhu kamar.

Penentuan bilangan iod bertujuan untuk menentukan kualitas minyak ikan dilihat dari ikatan rangkap pada asam lemak. Hasil analisa bilangan iod (Tabel 2) sampel minyak ikan A sebesar $18,57 \%$, sedangkan pada sampel B dan C sebesar $17,20 \%$ dan $16,01 \%$. Semakin tinggi suhu ekstraksi yang digunakan semakin rendah bilangan iod yang diperoleh. Hal ini sejalan dengan Lestari dkk., 2016), bahwa bilangan iod pada suhu $65^{\circ} \mathrm{C}$ yaitu sebesar $89,6 \mathrm{~g} / 100 \mathrm{~g}$ terus menurun hingga suhu $100{ }^{\circ} \mathrm{C}$ sebesar $80,56 \mathrm{~g} / 100 \mathrm{~g}$. Penggunakan suhu ekstraksi yang semakin meningkat akan memutus ikatan rangkap asam lemak tidak jenuh sehingga kualitas minyak menurun. Bilangan iod yang diperoleh pada penelitian ini lebih rendah daripada minyak isi perut ikan patin yaitu sebesar $86,82-103,18$ $\mathrm{g} / 100 \mathrm{~g}$ (Hastarini dkk., 2012). Hal tersebut menunjukan bahwa minyak isi perut ikan patin memiliki kandungan asam lemak tak jenuh yang lebih tinggi. Menurut Sari dkk. (2015), kualitas minyak ikan dikatakan semakin baik dilihat dari tingginya bilangan iod yang menandakan banyaknya jumlah ikatan rangkap atau asam lemak tak jenuhnya. Bilangan iod erat kaitannya dengan titik leleh minyak. Hasil bilangan iod sejalan dengan hasil slip melting point yang diperoleh, dimana sampel minyak ikan A memiliki bilangan iod yang tinggi terbukti dengan hasil slip melting pointnya pun menunjukan nilai terendah. Menurut Hasibuan \& Siahaan, (2013), semakin tinggi kandungan asam lemak tak jenuh maka semakin rendah pula titik lelehnya, namun sebaliknya semakin tinggi bilangan iod yang terkandung dalam minyak.

Analisis profil asam lemak dilakukan untuk mengetahui kandungan asam lemak yang ada dalam minyak ikan. Total SFA pada sampel A sebesar 38,95\% lebih rendah daripada sampel B dan C yaitu masingmasing sebesar $41,95 \%$ dan $42,9 \%$. Jenis asam lemak SFA yang paling dominan adalah asam palmitat, diikuti asam stearat dan asam miristat. Asam lemak ini bersifat stabil terhadap panas sehingga perlakuan suhu tinggi pada proses ekstraksi tidak mempengaruhi jumlahnya. Menurut Isamu dkk., (2017), asam palmitat, meristat, dan stearat lebih stabil terhadap pemanasan sehingga tidak mudah bereaksi dibandingkan asam lemak tak jenuh. Total MUFA tertinggi terdapat pada sampel minyak ikan A sebesar 34,53\% diikuti sampel B yaitu 33,05\% dan terendah pada sampel $\mathrm{C}$ sebesar $31,8 \%$. Asam oleat merupakan jenis asam lemak yang aling dominan dari ketiga sampel minyak ikan sehingga minyak isi perut ikan lele dapat dikatan berpotensi sebagai sumber asam lemak omega-9. Menurut Jamaluddin dkk., 2018), asam oleat atau sering disebut asam lemak omega-9 dapat berperan meningkatkan kadar kolesterol HDL dan menurunkan LDL dalam darah. Total PUFA tertinggi ditunjukkan pada sampel minyak ikan A yaitu sebesar 13,42\% kemudian diikuti sampel $B$ sebesar $13,2 \%$ dan terendah pada sampel $C$ yaitu sebesar $11,51 \%$. Jenis PUFA yang teridentifikasi adalah asam linoleat (omega-3) dan asam linolenat (omega-6). Hasil persentase asam linoleat yang diperoleh sejalan dengan kadar asam linoleat pada minyak ikan lele murni yaitu sebesar $12,37 \%$. Minyak ikan yang berasal dari air tawar seperti ikan lele, ikan gabus, dan ikan mas dapat dijadikan sebagai sumber asam lemak omega-6 (Srimiati dkk., 2015).

El-Rahman dkk., (2018) melaporkan bahwa total SFA minyak dari isi perut ikan nila sebesar $24,1 \%$, sedangkan total MUFA dan PUFA yaitu sebesar $72,32 \%$. Hasil tersebut lebih tinggi daripada hasil penelitian ini. Menurut Insani dkk. (2017), asam lemak pada tiap spesies akan berbeda karena dipengaruhi oleh beberapa faktor antara lain jenis spesies, suhu, habitat dan jenis makanan. Semakin tinggi suhu yang digunakan saat ekstraksi maka persentase MUFA dan PUFA pada minyak ikan semakin rendah. Asam lemak tak jenuh pada umumnya memiliki ikatan rangkap yang tidak stabil terhadap panas dan mudah mengalami oksidasi (Isamu dkk., 2017). Proses oksidasi diawali adanya interaksi antara peningkatan suhu dengan PUFA yang menyebabkan pelepasan oksigen, heme, dan zat besi yang mendorong pembentukan radikal bebas melalui proses autooksidasi. Oksidasi lemak meningkat seiring dengan banyaknya ikatan rangkap. PUFA teroksidasi 
lebih cepat daripada MUFA. Hal ini dikarenakan ikatan C-H pada ikatan rangkap merupakan ikatan lemah, sehingga dengan adanya sedikit energi mampu memutuskan atom hidrogen dari karbon ikatan rangkap, terutama pada karbon diantara dua ikatan rangkap (Amaral dkk., 2018). Hasil profil asam lemak pada penelitian ini sejalan dengan hasil bilangan iod dan slip melting point minyak ikan masing-masing perlakuan. Sampel A memiliki total SFA terendah namun kandungan MUFA dan PUFA tertinggi. Hal ini terbukti dengan bilangan iod sampel A merupakan hasil tertinggi dan memiliki titik leleh terendah daripada sampel B dan C.

Hasil kadar air tertinggi diperoleh pada sampel C yaitu sebesar $0,56 \%$, sedangkan sampel A dan B masing-masing sebesar $0,24 \%$ dan $0,48 \%$. Penggunaan suhu yang semakin tinggi dapat mengurangi kandungan air terikat pada jaringan sel karena air akan mudah menguap pada suhu tinggi. Kadar air yang diperoleh berkisar antara 0,24-0,56\%, lebih rendah dibandingkan kadar air minyak usus ikan nila yaitu sebesar 0,881,14\% (Nugroho dkk., 2014). Standar kadar air minyak ikan kasar yang ditetapkan oleh Badan Standarisasi Nasional (2013) yaitu maksimal 2\%, sedangkan menurut IFOMA (International Fishmeal and Oil Manufactured Association) yaitu berkisar antara 0,5-2\%. Berdasarkan standar yang ditetapkan maka sampel $\mathrm{C}$ memenuhi standar minyak ikan kasar secara nasional maupun internasional.

Hasil angka asam lemak bebas terendah diperoleh pada sampel minyak ikan A yaitu sebesar 1,52\%, sedangkan pada sampel $B$ dan $C$ berturut-turut sebesar $1,83 \%$ dan $2,00 \%$. Penggunaan suhu ekstraksi yang semakin tinggi dapat menghidrolisis trigliserida sehingga menghasilkan asam lemak bebas (Sopianti dkk., 2017). Selain itu, metode ekstraksi wet rendering dengan penambahan air dalam proses ekstraksinya dapat meningkatkan laju hidrolisis sehingga mempercepat kerusakan minyak yang ditandai dengan tingginya bilangan peroksida dan asam lemak bebas (Ayu dkk., 2019). Minyak isi perut ikan lele pada penelitian ini memiliki angka asam lemak bebas yang lebih rendah dibandingkan dengan minyak isi perut ikan nila dengan metode wet rendering yaitu sebesar 3,1\% (El-Rahman dkk., 2018) dan minyak ikan lele dengan metode $d r y$ rendering yaitu sebesar 2,44\% (Aditia dkk., 2014). Menurut Ayu dkk., (2019), kadar asam lemak bebas pada minyak dapat dipengaruhi oleh jenis bahan baku, metode ekstraksi, proses pemurnian minyak dan komposisi asam lemak. Kadar asam lemak bebas pada penelitian ini telah memenuhi standar minyak ikan kasar menurut Badan Standarisasi Nasional (2013) yaitu maksimal $1-2 \%$, dan menurut IFOMA yaitu berkisar antara $1-7 \%$.

Analisa bilangan peroksida atau proxide value (PV) bertujuan untuk mengetahui adanya hidrogen peroksida yang merupakan indikator penting dalam menentukan kualitas minyak ikan. Nilai PV tertinggi ditunjukkan pada sampel C yaitu sebesar 7,26 meq/ $\mathrm{kg}$, sedangkan sampel A dan B masing-masing sebesar 3,15 $\mathrm{meq} / \mathrm{kg}$ dan $4,24 \mathrm{meq} / \mathrm{kg}$. Hasil yang diperoleh lebih rendah daripada minyak ikan patin yaitu sebesar 38 $\mathrm{meq} / \mathrm{kg}$ (Nurjanah dkk., 2014) dan minyak limbah usus ikan nila sebesar 17,51 meq/kg (Nugroho dkk., 2014). Penggunaan suhu eksktaksi yang semakin tinggi akan menghasilkan senywa peroksida yang semakin tinggi pula. Menurut Burhan dkk., (2018), ikatan rangkap asam lemak tak jenuh pada minyak akan terputus apabila terkena suhu tinggi sehingga berikatan dengan oksigen membentuk senyawa peroksida menyebabkan kualitasnya menurun. Hasil PV dari ketiga sampel minyak ikan memenuhi standar minyak ikan kasar menurut IFOMA yaitu sebesar 3-20 meq/g, sedangkan

Tabel 2. Karakteristik ekstrak kasar minyak ikan lele (Clarias sp.)

\begin{tabular}{lccc}
\hline \multirow{2}{*}{ Parameter Uji } & \multicolumn{3}{c}{ Sampel minyak ikan } \\
\cline { 2 - 4 } & $\mathrm{A}$ & $\mathrm{B}$ & $\mathrm{C}$ \\
\hline Organoleptik & $8,64 \pm 0,49^{\mathrm{a}}$ & $8,24 \pm 0,60^{\mathrm{b}}$ & $7,87 \pm 0,52^{\mathrm{c}}$ \\
Rendemen (\%) & $3,40 \pm 0,53^{\mathrm{b}}$ & $5,15 \pm 0,59^{\mathrm{b}}$ & $8,57 \pm 1,05^{\mathrm{a}}$ \\
Slip melting point $\left({ }^{\circ} \mathrm{C}\right)$ & $29,27 \pm 0,51^{\mathrm{b}}$ & $35,43 \pm 0,35^{\mathrm{b}}$ & $37,53 \pm 0,31^{\mathrm{a}}$ \\
Bilangan iod (\%) & $18,57 \pm 0,64^{\mathrm{b}}$ & $17,20 \pm 0,63^{\mathrm{b}}$ & $16,01 \pm 0,19^{\mathrm{a}}$ \\
Kadar air (\%) & $0,24 \pm 0,11^{\mathrm{b}}$ & $0,48 \pm 0,13^{\mathrm{b}}$ & $0,56 \pm 0,04^{\mathrm{a}}$ \\
Asam lemak bebas (\%) & $1,52 \pm 0,14^{\mathrm{b}}$ & $1,82 \pm 0,04^{\mathrm{ab}}$ & $2,00 \pm 0,22^{\mathrm{a}}$ \\
Bilangan Peroksida (meq/kg) & $3,15 \pm 0,32^{\mathrm{b}}$ & $4,24 \pm 0,52^{\mathrm{b}}$ & $7,26 \pm 1,59^{\mathrm{a}}$ \\
\hline
\end{tabular}

Keterangan: Huruf yang berbeda pada baris yang sama menunjukkan perbedaan yang signifikan $(p>0,05)$

$\mathrm{A}=$ minyak isi perut ikan lele yang diekstrak dengan wet rendering suhu $80^{\circ} \mathrm{C}$

$\mathrm{B}=$ minyak isi perut ikan lele yang diekstrak dengan wet rendering suhu $90^{\circ} \mathrm{C}$

$\mathrm{C}=$ minyak isi perut ikan lele yang diekstrak dengan wet rendering suhu $100^{\circ} \mathrm{C}$ 
hanya sampel B yang memenuhi standar nasional yaitu menurut Badan Standarisasi Nasional (2013) standar PV yang ditetapkan sebesar 4-5 meq/kg.

Tabel 3. Profil asam lemak minyak isi perut ikan lele dengan suhu wet rendering yang berbeda

\begin{tabular}{lccc}
\hline \multirow{2}{*}{ Asam lemak } & \multicolumn{3}{c}{ Persentase asam lemak } \\
\cline { 2 - 4 } & $\mathrm{A}$ & $\mathrm{B}$ & $\mathrm{C}$ \\
\hline Asam kaprilat (C8:0) & 0,84 & 1,04 & 2,59 \\
Asam kaprat (C10:0) & 0,39 & 0,54 & 1,37 \\
Asam laurat (C12:0) & 0,32 & 0,30 & 0,30 \\
Asam miristat (C14:0) & 1,63 & 1,45 & 1,28 \\
Asam palmitat (C16:0) & 32,19 & 34,73 & 32,93 \\
Asam stearat (C18:0) & 3,42 & 3,72 & 4,00 \\
Asam linoserat (C24:0) & 0,16 & 0,17 & 0,43 \\
Total SFA & 38,95 & 41,95 & 42,9 \\
\hline Asam palmitoleat (C16:1n-7) & 6,64 & 5,35 & 6,81 \\
Asam oleat (C18:1n-9) & 27,89 & 27,70 & 24,99 \\
Total MUFA & 34,53 & 33,05 & 31,8 \\
\hline Asam linoleat (C18:2n-6) & 12,99 & 12,74 & 11,17 \\
Asam linolenat (C18:3n-3) & 0,43 & 0,46 & 0,34 \\
Total PUFA & 13,42 & 13,2 & 11,51 \\
\hline Total SFA, MUFA \& PUFA & 86,9 & 88,2 & 86,21 \\
\hline
\end{tabular}

Keterangan:

$\mathrm{A}=$ minyak isi perut ikan lele yang diekstrak dengan wet rendering suhu $80^{\circ} \mathrm{C}$

$\mathrm{B}=$ minyak isi perut ikan lele yang diekstrak dengan wet rendering suhu $90^{\circ} \mathrm{C}$

$\mathrm{C}=$ minyak isi perut ikan lele yang diekstrak dengan wet rendering suhu $100^{\circ} \mathrm{C}$

\section{KESIMPULAN}

Suhu ekstraksi wet rendering yang berbeda memberikan pengaruh yang nyata terhadap karakteristik ekstrak kasar minyak isi perut ikan lele. Suhu optimum ekstraksi wet rendering terbaik adalah $100{ }^{\circ} \mathrm{C}$ dengan hasil rendemen minyak tertinggi, mempunyai karakteristik yang memenuhi standar kimia dan organoleptik minyak ikan kasar. Ekstraksi wet rendering dengan suhu 100 ${ }^{\circ} \mathrm{C}$ menghasilkan minyak dengan rendemen $8,57 \%$, slip melting point $37,53{ }^{\circ} \mathrm{C}$, bilangan iod $16,01 \%$, total SFA $42,9 \%$, MUFA $31,8 \%$, PUFA $11,51 \%$, angka asam lemak bebas $2,00 \%$, kadar air $0,56 \%$, bilangan peroksida $7,26 \mathrm{meq} / \mathrm{kg}$ dan karakteristik organoleptik minyak yang jernih, berwarna kuning sedikit kecoklatan dan berbau sedikit asam tapi bukan tengik. Produk penelitian ini berkontribusi pada peningkatan nilai tambah hasil samping produk perikanan terutama isi perut ikan lele. Selain itu, ekstrak minyak ikan lele dapat diaplikasikan pada produk pangan dengan melalui tahapan proses refining.

\section{UCAPAN TERIMA KASIH}

Penulis mengucapkan terimakasih kepada Universitas Diponegoro yang telah membiayai penelitian ini melalui dana Riset Pengembangan dan Penerapan 2019.

\section{KONFLIK KEPENTINGAN}

Penelitian ini tidak terdapat konflik kepentingan antar penulis atau dengan pihak lainnya.

\section{DAFTAR PUSTAKA}

Aditia, R. P., Darmanto, Y. S., \& Romadhon. (2014). Perbandingan mutu minyak ikan kasar yang diekstrak dari berbagai jenis ikan yang berbeda. Jurnal Pengolahan dan Bioteknologi Hasil Perikanan, 3(3), 55-60.

AOAC. (1995). Guidelines for single laboratory validation of chemical methods for dietary supplements and botanicals. AOAC International, 1-38.

AOAC. (2007). Guidelines for single laboratory validation of chemical methods for dietary supplements and botanicals. AOAC International, 1-38.

Amaral, A. B., Solva, M. V. Da, \& Lannes, S. C. D. S. (2018). Lipid oxidation in meat: Mechanisms and protective factors - a review. Food Science and Technology, 38, 1-15. https://doi.org/10.1590/fst.32518

Ayu, D. F., Diharmi, A., \& Ali, A. (2019). Karakteristik minyak ikan dari lemak abdomen hasil samping. JPHPI, 22(1), 187-197.

Badan Standarisasi Nasional. 2013. SNI 2730.1:2013. Minyak Hati Ikan Cucut Botol Mentah (Crude Shark Liver Oi). Jakarta: Badan Standarisasi Nasional.

Bako, T., Umogbai, V. I., \& Awulu, J. O. (2017). Criteria for the extraction of fish oil. Agricultural Engineering International: CIGR Journal, 19(3), 120-132.

Bonilla-Mendez, J. R., \& Hoyos-Concha, J. L. (2018). Methods of extraction, refining and concentration of fish oil as a source of omega-3 fatty acids. Corpoica Ciencia y Tecnologia Agropecuaria, 19(3), 645-668. https://doi. org/10.21930/rcta.vol19_num2_art:684

Burhan, A. H., Rini, Y. P., Faramudika, E., \& Widiastuti, R. (2018). Penetapan angka peroksida minyak goreng curah sawit pada penggorengan berulang ikan lele. Jurnal Pendidikan Sains, 6(2), 48-53. https://doi. org/10.26714/jps.6.2.2018.48-53 
David, W., \& Djamaris, A. R. A. (2018). Metode statistik untuk ilmu dan teknologi pangan. http://repository.bakrie. ac.id/1255/1/Ilmu Statistik ITP.pdf

Deepika, D., Vegneshwaran, V. R., Julia, P., Sukhinder, K. C., Sheila, T., Heather, M., \& Wade, M. (2014). Investigation on oil extraction methods and its influence on omega-3 content from cultured salmon. Journal of Food Processing \& Technology, 5(12), 1-13. https://doi.org/10.4172/21577110.1000401

Devadason, C., Jayasinghe, C., Sivakanesan, R., Senarath, S., Beppu, F., \& Gotoh, N. (2016). Comparative analysis of lipid content and fatty acid composition of commercially important fish and shellfish from Sri Lanka and Japan. Journal of Oleo Science, 65(7), 1-15. https://doi. org/10.5650/jos.ess 16056

Edea, G. O., Montchowui, E., Hinvi, L. C., Abou, Y., Gbangboche, A. B., \& Laleye, P. A. (2018). Proximate composition of cultured (oreochromis niloticus) and (clarias gariepinus) based on commercial feed in benin. International Journal of Agriculture, Environment and Bioresearch, 3(05), 176-183. https://doi.org/10.13140/ RG.2.2.36693.68320

Effiong, B. N., \& Fakunle, J. O. (2013). Fatty acid composition of catfish (Clarias gariepinus) viscera oil. Journal of Fisheries and Aquatic Science, 8(1), 299-301. https:// doi.org/10.39231jfas.2013.299.301

Eka, B., Junianto, \& Rochima, E. (2016). Pengaruh metode rendering terhadap karakteristik fisik, kimia dan organoleptik ekstrak kasar minyak ikan lele. Jurnal Perikanan Kelautan, 7(1), 1-5. https://doi.org/10.2903/j. efsa.2010.1874

El-Rahman, F. A., Mahmoud, N. S., El-Khair Badawy, A., \& Youns, S. M. (2018). Extraction of fish oil from fish viscera. Egyptian Journal of Chemistry, 61(2), 225-235. https://doi.org/10.21608/ejchem.2018.2798.1230

Elbossaty, W. F. (2018). Clinical influence of triple omega fatty acids (Omega-3, 6, 9). Biomedical Journal of Scientific \& Technical Research, 6(3), 5332-5334. https://doi. org/10.26717/bjstr.2018.06.001383

Fouda, T. (2018). Waste management for smoking salmon by-products to extract omega-3 fish oil. Fisheries and Aquaculture Journal, 09(03), 12-14. https://doi. org/10.4172/2150-3508.1000253

Hasanah, F., Lestari, N., \& Adiningsih, Y. (2017). Pengendalian senyawa trimetilamin (TMA) dan amonia dalam pembuatan margarin dari minyak patin. Warta Industri Hasil Pertanian, 34(2), 72-80. https://doi.org/10.32765/ wartaihp.v34i2.3566

Hasibuan, H. A., \& Siahaan, D. (2013). Penentuan bilangan iod dan titik leleh berdasarkan kandungan lemak padat minyak sawit dan minyak inti sawit. Jurnal
Standardisasi, 15(1), 47-57. http://js.bsn.go.id/index. php/standardisasi/article/download/658/325

Hastarini, E., Fardiaz, D., Irianto, H. E., \& Budijanto, S. (2012). Karakteristik minyak ikan dari limbah pengolahan filet ikan patin siam (Pangasius hypopthalmus) dan patin jambal (Pangasius djambal). agiTECH, 32(4), 403-410. https://doi.org/10.22146/agritech.9584

Hildawianti, Tiwow, V. M. A., \& Abram, P. H. (2017). Analisis kandungan nitrogen $(\mathrm{N})$ dan posforus $(\mathrm{P})$ pada limbah jeroan ikan mujair (Oreochromis mosambicus) Danau Lindu. Jurnal Akademika Kimia, 6(3), 148-153. https:// doi.org/10.22487/j24775185.2017.v6.i3.9425

IFOMA. (1998). International Fishmeal and Oil Manufactures Association. Hertfordshire. United Kingdom.

Insani, S. A., Suseno, S. H., \& Jacoeb, A. M. (2017). Karakteristik squalene minyak hati ikan cucut hasil produksi industri rumah tangga, Pelabuhan Ratu. JPHPI, 20(3), 494-504. www.journal.ipb.ac.id/index.php/jphpi

Isamu, K. T., Ibrahim, M. N., Mustafa, A., \& Sarnia. (2017). Profil asam lemak ikan gabus (Channa striata) asap yang diproduksi dari Kabupaten Konawe Sulawesi Tenggara. Jurnal Sains dan Teknologi Pangan, 2(6), 941-948.

Jamaluddin, Amelia, P., \& Widodo, A. (2018). Studi perbandingan komposisi asam lemak daging ikan sidat (Anguilla marmorata (Q.) Gaimard) fase yellow eel dari Sungai Palu dan Danau Poso. Jurnal Farmasi Galenika, 4(1), 73-78. https://doi.org/10.22487/j24428744.2018.v4.i1.10035

Kamini, Suptijah, P., Santoso, J., \& Suseno, S. H. (2016). Ekstraksi dry rendering dan karakterisasi minyak ikan dari lemak jeroan hasil samping pengolahan salai patin siam. JPHPI, 19(3), 196-205. https://doi.org/10.17844/ jphpi.2016.19.3.196

Kementrian Kelautan dan Perikanan. (2017). Dashboard Produksi Nasional 2017. https://satudata.kkp.go.id/ dashboard_produksi/. (21 Juli 2019).

Lestari, R. R., Ibrahim, R., \& Riyadi, P. H. (2016). Perbedaan suhu pengolahan dengan metode steam jacketed sederhana terhadap mutu minyak dari limbah kepala ikan mackerel (Scomber japonicus). Jurnal Saintek Perikanan, 11(2), 78-83.

Nazir, N., Diana, A., \& Sayuti, K. (2017). Physicochemical and fatty acid profile of fish oil from head of tuna (Thunnus albacares) extracted from various extraction method. International Journal on Advanced Science, Engineering and Information Technology, 7(2), 709-715. https:// doi.org/10.18517/ijaseit.7.2.2339

Ngadiarti, I., Kusharto, C. M., Briawan, D., Marliyati, S. A., \& Sayuthi, D. (2013). Kandungan asam lemak dan karakteristik fisiko-kimia minyak ikan lele dan minyak ikan lele terfermentasi. Jurnal Penelitian Gizi dan Makanan, 36(1), 82-90. 
Nugroho, A., Ibrahim, R., \& Riyadi, P. (2014). Pengaruh perbedaan suhu pengukusan (steam jacket) terhadap kualitas minyak dari limbah usus ikan nila (Oreochromis niloticus). Jurnal Pengolahan dan Bioteknologi Hasil Perikanan, 3(1), 21-29.

Nurjanah, Suseno, S. H., \& Arifianto, T. B. (2014). Ekstraksi dan karakterisasi minyak dari kulit ikan patin (Pangasius hypophthalmus). Depik, 3(3), 250-262.

Obaroh, I. O., Haruna, M. A., \& Ojibo, A. (2015). Comparative study on proximate and mineral element composition of clarias gariepinus from the cultured and wild sources. European Journal of Basic and Applied Sciences, 2(2), 19-26. www.idpublications.org

Raharjo, S., Su'i, M., \& Suprihana, S. (2017). Pengaruh penambahan pewarna ekstrak kunyit dan ekstrak wortel terhadap margarin berbahan minyak kelapa dan lemak coklat. Jurnal Ilmu-Ilmu Pertanian "Agrika," 11(2), 135145. https://doi.org/10.31328/ja.v11i2.488

Sari, R. N., Utomo, B. S. B., Basmal, J., \& Kusumawati, R. (2015). Pemurnian minyak ikan hasil samping (precooking) industri pengalengan ikan lemuru (Sardinella lemuru). JPHPI, 18(3), 276-286. https://doi. org/10.17844/jphpi.2015.18.3.276

Sopianti, D. S., Herlina, \& Saputra, H. T. (2017). Penetapan kadar asam lemak bebas pada minyak goreng. Jurnal Katalisator, 2(2), 100-105.

Srimiati, M., Kusharto, C. M., Tanziha, I., \& Suseno, S. H. (2015). Effect of different bleaching temperatures on the quality of refined catfish (Clarias gariepinus) Oil. Procedia Food Science, 3, 223-230. https://doi. org/10.1016/j.profoo.2015.01.025
Suseno, S H, Tajul, A. Y., Nadiah, W. A., \& Noor, A. F. (2012). Improved of color properties on sardinella lemuru oil during adsorbent refining using magnesol xl. International Food Research Journal, 19(4), 1383-1386.

Suseno, Sugeng H., Nurjanah, N., Yoshiara, \& Saraswati. (2015). Determination of extraction temperature and period of fish oil from Tilapia (Oreochromis niloticus) by product using wet rendering method. KnE Life Sciences, 1(1), 125. https://doi.org/10.18502/kls.v1i0.96

Taati, M. M., Shabanpour, B., \& Ojagh, M. (2018). Investigation on fish oil extraction by enzyme extraction and wet reduction methods and quality analysis. $A A C L$ Bioflux, 11(1), 83-90.

Widiyanto, W. N., Ibrahim, R., \& Anggo, A. D. (2015). Pengaruh suhu pengolahan dengan metode steam jacket sederhana terhadap kualitas minyak ikan hati pari mondol. JPHPI, 18(1), 11-18. https://doi.org/10.17844/ jphpi.2015.18.1.11

Wijaya, T. H., Kartawinata, T. G., \& Nugrahani, I. (2019). Pengujian mutu sediaan kapsul minyak hati ikan cucut botol dalam beberapa produk yang beredar di pasaran. Pharmaceutical Sciences and Research, 6(3), 170-178. https://doi.org/10.7454/psr.v6i3.4174

Yesmin, S., \& Khanum, H. (2019). Biochemical analysis of different nutritional components of Clarias batrachus (Linnaeus) and Clarias gariepinus (Burchell) in relation to parasitic infestation. Bangladesh Journal of Zoology, 47(1), 27-39. https://doi.org/10.3329/bjz.v47i1.42018 